\section{Heat Treatment of Pre-hydrolyzed Silane Increases Adhesion of Phosphate Monomer-based Resin Cement to Glass Ceramic}

\author{
Rodrigo Furtado de Carvalho' ${ }^{1}$, Caroline Cotes², Estevão Tomomitsu Kimpara² ${ }^{2}$ \\ Fabíola Pessoa Pereira Leite ${ }^{3}$, Mutlu Özcan ${ }^{4}$
}

\author{
'Department of Dentistry, Dental \\ School, UFJF - Federal University \\ of Juiz de Fora, Governador \\ Valadares, MG, Brazil \\ ${ }^{2}$ Department of Dental Materials \\ and Prosthodontics, São José dos \\ Campos Dental School, UNESP \\ - Univ Estadual Paulista, São \\ José dos Campos, SP, Brazil \\ ${ }^{3}$ Department of Restorative \\ Dentistry, Dental School, UFJF \\ - Federal University of Juiz de \\ Fora, Juiz de Fora, MG, Brazil \\ ${ }^{4}$ Clinic for Fixed and Removable \\ Prosthodontics and Dental Materials \\ Science, Center for Dental and \\ Oral Medicine, University of \\ Zürich, Zürich, Switzerland \\ Correspondence: Dr. Rodrigo Furtado \\ de Carvalho, Campus Antônio \\ Rodrigues Coelho, Bloco D9, Depto. \\ de Odontologia, Rua lsrael Pinheiro, \\ 2000, Bairro Universitário, 35020- \\ 220 Governador Valadares, MG. \\ Tel.:+55-32-8875-0422. e-mail: \\ rf-carvalho@hotmail.com
}

This study evaluated the influence of different forms of heat treatment on a pre-hydrolyzed silane to improve the adhesion of phosphate monomer-based (MDP) resin cement to glass ceramic. Resin and feldspathic ceramic blocks ( $n=48, n=6$ for bond test, $n=2$ for microscopy) were randomly divided into 6 groups and subject to surface treatments: G1: Hydrofluoric acid (HF) 9.6\% for $20 \mathrm{~s}+$ Silane + MDP resin cement (Panavia F); G2: HF 9.6\% for $20 \mathrm{~s}+$ Silane + Heat Treatment (oven) + Panavia F; G3: Silane + Heat Treatment (oven) + Panavia F; G4: HF 9.6\% for $20 \mathrm{~s}+$ Silane + Heat Treatment (hot air) + Panavia F; G5: Silane + Heat Treatment (hot air) + Panavia F; G6: Silane + Panavia F. Microtensile bond strength (MTBS) test was performed using a universal testing machine $(1 \mathrm{~mm} / \mathrm{min})$. After debonding, the substrate and adherent surfaces were analyzed using stereomicroscope and scanning electron microscope (SEM) to categorize the failure types. Data were analyzed statistically using two-way test ANOVA and Tukey's test $(\alpha=0.05)$. Heat treatment of the silane containing MDP, with prior etching with $\mathrm{HF}(\mathrm{G} 2: 13.15 \pm 0.89 \mathrm{a} ; \mathrm{G} 4$ : $12.58 \pm 1.03 a$ ) presented significantly higher bond strength values than the control group (G1: $9.16 \pm 0.64 b)$. The groups without prior etching (G3: 10.47 $\pm 0.70 b ; G 5: 9.47 \pm 0.32 b$ ) showed statistically similar bond strength values between them and the control group (G1). The silane application without prior etching and heat treatment resulted in the lowest mean bond strength (G6: $8.05 \pm 0.37 \mathrm{c}$ ). SEM analysis showed predominantly adhesive failures and EDS analysis showed common elements of spectra ( $\mathrm{Si}, \mathrm{Na}, \mathrm{Al}, \mathrm{K}$, $0, C)$ characterizing the microstructure of the glass-ceramic studied. Heat treatment of the pre-hydrolyzed silane containing MDP in an oven at $100{ }^{\circ} \mathrm{C}$ for $2 \mathrm{~min}$ or with hot air application at $50 \pm 5^{\circ} \mathrm{C}$ for $1 \mathrm{~min}$, was effective in increasing the bond strength values between the ceramic and resin cement containing MDP.

\section{Introduction}

Dental ceramics are popular choice of materials for almost all aesthetic restorative procedures because of their high compressive strength, abrasion resistance, chemical stability, biocompatibility, favorable optical properties, translucency, fluorescence and thermal expansion coefficient similar to tooth structure (1).

Feldspathic ceramic is widely used for the fabrication of indirect restorations and veneers that consists of two minerals, namely feldspar and quartz. The feldspar is attached to metal oxides and forms the glass phase, while the quartz composes the crystalline phase. Feldspathic ceramics are classified as biphasic glass and are often composed of $\mathrm{Si}, \mathrm{Al}, \mathrm{K}, \mathrm{Na}, \mathrm{Ca}, \mathrm{C}$, and $\mathrm{O}$ (2), which is recommended for veneers and indirect restorations (inlays, onlays, overlays). Feldspathic ceramics are classified as acidsensitive, as the surface of this ceramic can be degraded by $9.6 \%$ hydrofluoric acid (HF) that creates a topographic pattern that promotes micromechanical retention (2-4).

Prior to adhesive luting, it is recommended to prepare the restoration surface with various chemicals, such as silane coupling agent, a monomer composed of reactive organic radicals and monovalent hydrolyzable groups that promote a chemical union between the ceramic inorganic phase and the bonding agent organic phase applied to the ceramic surface through siloxane bonds $(1,2,5)$. Furthermore, silane increases the surface energy of a ceramic substrate and improves the wetting of the luting agent, optimizing the microscopic interaction between the cement and the ceramic. The effectiveness of a silane coupling agent may vary depending on its chemical composition, storage form and age of the product due to its chemical instability (5).

The $9.6 \% \mathrm{HF}$ is highly caustic (level 2) and requires caution when using it in a dental practice. The use of heat treatment protocols of silane may eliminate the use of $\mathrm{HF}$ for etching the ceramic restoration, prior to adhesive luting. After silanization of the prosthetic restoration, the restoration would be typically heat treated in an oven for $2 \mathrm{~min}$ at $100{ }^{\circ} \mathrm{C}$. This treatment allows for the removal of water, alcohol and other by-products of the silanized ceramic surface, and helps completing the condensation 
reaction between silica and silane. This forms a covalent bond at the silane-ceramic interface, making this adhesion more effective and strong (6-8).

The objective of this study was to evaluate the influence of different forms of heat treatment on a pre-hydrolyzed silane to improve the adhesion of phosphate monomerbased (MDP) resin cement to glass ceramic.

\section{Material and Methods}

\section{Specimen Preparation}

The ceramic powder (Dentin 5M2, VITA VM7; Vita Zahnfabrik, Bad Säckingen, Germany) and modelling liquid (Vita Zahnfabrik) were mixed according to the manufacturer's instructions. The mixture was placed in small portions using a spatula, condensed inside the silicon impression and vibrated manually until filling the entire space. Any excess fluid was removed with soft absorbent paper. The ceramic block was then removed from the mould. Ceramic blocks $(n=48)$ were prepared from the single impression and were fired on the refractory base of a ceramic oven (Vacumat, Vita Zahnfabrik) following the firing cycles recommended by the manufacturer. Considering that the contraction of sintering of ceramics is approximately $20 \%$, post-sintered blocks had approximate dimensions of $4.8 \mathrm{~mm} \times 6.4 \mathrm{~mm} \times 6.4 \mathrm{~mm}$. The internal surfaces of each block underwent a radiographic evaluation in order to observe possible faults within the ceramic body. When flaws were noted, new ceramic specimens were prepared. Then, excess ceramic was removed with diamond discs at low speed. The bond surfaces were manually polished under water irrigation and using 600-, 800-, 1000-, and 1200grit silicone carbide paper. The specimens were cleaned ultrasonically in distilled water for $5 \mathrm{~min}$.

Impression of each ceramic block was made using heavy polysiloxane putty (Elite HD, Zhermack, Rovigo, Italy) inside a plastic container with the adhesive surface facing downward. After setting of the impression material, each ceramic block was removed from the mould and a microhybrid composite resin (W3D Master; Wilcos, Petrópolis, RJ, Brazil) was incrementally placed. Each increment was photo-activated for $40 \mathrm{~s}$ (Ultraled; Ultradent, South Jordan, UT, USA) until the mould was filled, resulting in a block of microhybrid resin composite $(4.8 \mathrm{~mm} \times 6.4$ $\mathrm{mm} \times 6.4 \mathrm{~mm}$ ) for each ceramic block. As a result, the bond surface of resin composite had the same dimensions as the surface of the ceramic block.

\section{Surface Conditioning and Heat Treatment Protocols}

The ceramic and composite blocks were randomly divided into six groups $(n=8)$ and conditioned according to one of the following protocols:

Group 1: HF 9.6\% for $20 \mathrm{~s}+$ Silane + MDP based resin cement (Panavia F2.0; Kuraray Medical Inc., Okayama, Japan); Group 2: HF 9.6\% for $20 s$ + Silane + Heat treatment (oven) + Panavia F2.0; Group 3: Silane + Heat treatment (oven) + Panavia F2.0: Group 4: HF 9.6\% for $20 \mathrm{~s}+$ Silane + Heat treatment (hot air) + Panavia F2.0; Group 5: Silane + Heat treatment (hot air) + Panavia F2.0; Group 6: Silane + Panavia F2.0

Groups 1, 2 and 4 were conditioned with HF Porcelain Conditioner (Dentsply, Catanduva, SP, Brazil) for $20 \mathrm{~s}$, then rinsed with water spray for $60 \mathrm{~s}$, cleaned ultrasonically in distilled water for $4 \mathrm{~min}$, and dried with air spray for $30 \mathrm{~s}$.

The bonding surface of each ceramic block was silanized using an MDP based silane coupling agent (Clearfil Ceramic Primer; Kuraray Medical Inc.) which was dried completely with air spray. Then the cementation process was performed as recommended by the manufacturer.

After silane application, the ceramic blocks from Groups 2 and 3 were placed in an oven (F1800; EDG, São Paulo, $\mathrm{SP}$, Brazil) at $100{ }^{\circ} \mathrm{C}$ for $2 \mathrm{~min}$ for heat treatment of the silane (9). The ceramic blocks from Groups 4 and 5 were silanized and hot air hair dried (Gradiente, São Paulo, SP, Brasil) at $50 \pm 5{ }^{\circ} \mathrm{C}$ for $1 \mathrm{~min}(7)$.

\section{Specimen Cementation}

After surface treatment of the ceramics, composite blocks were bonded to silanized surfaces of the ceramic blocks using dual polymerized cement Panavia F2.0 that was mixed according to the manufacturer's recommendations and applied with a plastic spatula on the prepared surface of each ceramic block.

The ceramic-resin composite assembly was placed in an adapted surveyor for cementing with the cementation surfaces perpendicular to a static vertical load of 750 for $10 \mathrm{~min}$. The excess cement was then removed. The cement was photo-polymerized for $40 \mathrm{~s}$ from each direction at the bonded sites of the assembly using LED curing unit (UItra LED; Ultradent, South Jordan, UT, USA) after loading.

The ceramic-cement-resin assembly was washed with air-water spray and stored in distilled water at $37^{\circ} \mathrm{C}$ for 7 days until the specimens were prepared for the microtensile bond strength test.

\section{Microtensile Bond Strength Test}

Each specimen was fixed with cyanoacrylate adhesive (Super Bonder Gel; Loctite, São Paulo, SP, Brazil) to a plate adapted to a cutting device (Isomet 1000; Buehler, Lake Buff, IL, USA). The cuts were made with a diamond wheel $(15.2 \mathrm{~mm} \times 0.5 \mathrm{~mm}$ ) (Buehler) at slow speed (200 rpm) under copious irrigation at a load $100 \mathrm{kgf}$, starting in resin and cutting into the ceramic to obtain sticks of about $1 \mathrm{~mm}$ thick. The assembly was the rotated $90^{\circ}$ and subjected to further cuts to obtain sticks. 
The external $1 \mathrm{~mm}$ section was discarded due to the risk of having excess cement around the adhesive interface influencing the microtensile resistance. The following sections were turned $90^{\circ}$ and were fixed again on the metallic base and sticks were obtained with bonded area of $1 \pm 0.05 \mathrm{~mm}^{2}$. The same process was performed for two further sectioning, resulting in nine sticks for each ceramic-cement-composite resin assembly, presenting the following characteristics: rectangle shape, quadrangular symmetric transversal section, adhesive area: $1 \pm 0.05 \mathrm{~mm}^{2}$, length: $8 \mathrm{~mm}$.

The specimens were placed in a universal testing machine (Model DL-1000; EMIC, São José dos Pinhais, PR, Brazil) with the bonding surface perpendicular to a 10 $\mathrm{kgf}$ load cell to avoid any bending forces in the adhesive region. Each specimen was loaded to failure at $1 \mathrm{~mm} / \mathrm{min}$.

\section{Failure Analysis}

After bond tests, failure types were initially analyzed using a stereoscopic microscope (ZEISS MC 80 DX; Carl Zeiss, Branson, MO, USA) at 50× magnification. Failures were classified as: a) adhesive and b) cohesive (cohesive in ceramic or resin composite).

Representative failure types in each group were further analyzed under Scanning Electron Microscope (SEM) (JeolJSM-T330A; Jeol Ltd., Tokyo, Japan) at 150× magnification.

\section{Topographic Analysis}

Separate ceramic blocks $(n=12)$ were fabricated for each group for topography analysis under SEM and X-ray energy dispersive spectrometry (EDS). The ceramic surfaces were observed under SEM at 500x and 2000x magnification at a low vacuum level of $40 \mathrm{~Pa}, 20 \mathrm{kV}$, at a working distance of $15 \mathrm{~mm}$. A chemical assessment of the specimens was performed using the EDS where energy characteristics of

Table 1. Bond strength means and standard deviations (S.D.) (MPa) obtained for different methods of conditioning

\begin{tabular}{lc}
\hline Group & $\begin{array}{c}\text { Bond } \\
\text { strength (SD) }\end{array}$ \\
\hline G1: HF + Silane + Panavia F2.0 & $9.16 \pm 0.64^{\mathrm{b}}$ \\
G2: HF + Silane + heat treatment & $13.15 \pm 0.89^{\mathrm{a}}$ \\
(furnace) + Panavia F2.0 & \\
$\begin{array}{l}\text { G3: Silane + heat treatment } \\
\text { (furnace) + Panavia F2.0 }\end{array}$ & $10.47 \pm 0.70^{\mathrm{b}}$ \\
G4: HF + Silane + heat treatment & $12.58 \pm 1.03^{\mathrm{a}}$ \\
(hot air) + Panavia F2.0 & $9.47 \pm 0.32^{\mathrm{b}}$ \\
G5: Silane + heat treatment (hot air) + Panavia & $8.05 \pm 0.37^{\mathrm{c}}$ \\
\hline
\end{tabular}

Different letters indicate statistically significant difference at $\mathrm{p}<0.05$.
X-rays released from the specimen and the incidence of electron bundles are evaluated.

\section{Statistical Analysis}

Bond strength data (MPa) were submitted to two-way analysis of variance using SPSS software for Windows (SPSS, version 11, Chicago, IL, USA), and $p$ values less than 0.05 were considered to be statistically significant in all tests.

\section{Results}

During the cutting procedures, 3 and 2 pre-test failures were experienced in Groups 3 and 6, respectively. These failed sticks were discarded from the statistical analysis (6).

Heat treatment of the silane containing MDP, with prior etching with HF (G2: $13.15 \pm 0.89 ; \mathrm{G} 4: 12.58 \pm 1.03)$ presented significantly higher bond strength values than the control group (G1: $9.16 \pm 0.64$ ) (Table 1). The groups without prior etching (G3: 10.47 $\pm 0.70 ; \mathrm{G} 5$ : $9.47 \pm 0.32$ ), had statistically similar bond strength values between them and the control group (G1). The silane application without prior etching and heat treatment resulted in the lowest mean bond strength (G6: $8.05 \pm 0.37$ ).

Failure types were predominantly adhesive (Table 2).

Table 2. Distribution of failures types per group after debonding according to stereomicroscopy analysis. For group descriptions see Table 1

\begin{tabular}{|c|c|c|c|c|}
\hline Group & $\begin{array}{l}\text { Sample } \\
\text { size }\end{array}$ & $\begin{array}{c}\text { Adhesive (at } \\
\text { ceramic/cement } \\
\text { interface }\end{array}$ & $\begin{array}{l}\text { Cohesive } \\
\text { in the } \\
\text { ceramic }\end{array}$ & $\begin{array}{c}\text { Cohesive } \\
\text { in the } \\
\text { resin }\end{array}$ \\
\hline $\begin{array}{l}\text { G1: HF + } \\
\text { Silane + } \\
\text { Panavia F2.0 }\end{array}$ & 72 & 69 & 1 & 2 \\
\hline $\begin{array}{l}\mathrm{G} 2: \mathrm{HF}+ \\
\text { Silane + heat } \\
\text { treatment } \\
\text { (furnace) + } \\
\text { Panavia F2.0 }\end{array}$ & 72 & 70 & 1 & 1 \\
\hline $\begin{array}{l}\text { G3: Silane } \\
+ \text { heat } \\
\text { treatment } \\
\text { (furnace) + } \\
\text { Panavia F2.0 }\end{array}$ & 72 & 69 & - & 3 \\
\hline $\begin{array}{l}\mathrm{G} 4: \mathrm{HF}+ \\
\text { Silane + heat } \\
\text { treatment } \\
\text { (hot air) + } \\
\text { Panavia F2.0 }\end{array}$ & 72 & 69 & 2 & 1 \\
\hline $\begin{array}{l}\text { G5: Silane } \\
+ \text { heat } \\
\text { treatment } \\
\text { (hot air) + } \\
\text { Panavia }\end{array}$ & 72 & 70 & 1 & 1 \\
\hline $\begin{array}{l}\text { G6: Silane + } \\
\text { Panavia F2.0 }\end{array}$ & 72 & 72 & - & - \\
\hline
\end{tabular}


EDS analysis showed common elements of spectra $(\mathrm{Si}, \mathrm{Na}, \mathrm{Al}, \mathrm{K}, \mathrm{O}, \mathrm{C})$ characterizing the microstructure of the glass-ceramic studied which is based on a network of silica $\left(\mathrm{SiO}_{2}\right)$ and feldspar of potassium $\left(\mathrm{Al}_{2} \mathrm{O}_{3} \mathrm{~K} 2 \mathrm{O} .6 \mathrm{SiO}_{2}\right)$ or sodium $\left(\mathrm{Al}_{2} \mathrm{O}_{3} \mathrm{Na}_{2} \mathrm{O} .6 \mathrm{SiO}_{2}\right)$ or both (Fig. 1)

\section{Discussion}

During the adhesive cementation of a ceramic restoration, many factors can influence its adhesion to the tooth structure. After luting, two interfaces are obtained, one being between the resin cement and ceramic restoration and the other between the resin cement and tooth substance. In this study, the bond strength of the interface formed by the ceramic and the resin cement were evaluated with a microtensile bond strength test (9-11).

Essentially, HF etching creates a micromorphology pattern on the ceramic surface, leading to the formation of microporosities that facilitate interconnection with the polymers and alter the wettability of the ceramic surface $(3,4,12)$. However, $\mathrm{HF}$ is extremely caustic and harmful, and should be used with caution or even clinically avoided (2). The adhesion between resin and ceramic can be obtained by the proper application of silane without conditioning the ceramic surface with HF $(6,7)$.

Since there was no significant difference between the groups with (Group 1) and without etching (Groups 3 and 5), it can be stated that HF can be avoided when silane is activated with heat treatment. This could be attributed to the use of a pre-hydrolyzed silane containing MDP, that interacts with the inorganic substrate, represented by the silicon contained in the glass matrix feldspathic ceramic, and the organic polymers such as MDP which is found in the resin luting agent, Panavia F2.0. The application of silane on the etched ceramic surface, may further lead a dissociation of fluorsilicate salts (13). This occurs as a result of hydrolysis and absorption of the silane on the etched surfaces. Another important factor is the ability of silane to promote better wetting of the surface, leading to greater contact and infiltration of the bonding agent on the porosity of the ceramic surface by etching with HF (2).

Silane coupling agents can be in a single phase of a pre-activated system or two phases system that needs to be mixed in order to start the hydrolysis reaction. Pre-activated silane solutions are composed of three ingredients: silane coupling agent, acid component and solvent (14). The silane heat treatment allows for the removal of water, alcohol and other by-products from the silanized ceramic surface, and helps to complete the condensation reaction between the silica and silane, promoting the formation of a covalent bond in the silane-ceramic interface that eventually makes the adhesion more durable (6-8). There are different methods for performing heat treatment of the silane such as in an oven set at $100^{\circ} \mathrm{C}$ for $2 \mathrm{~min}(9)$ or hot air application at $50 \pm 5^{\circ} \mathrm{C}$ for $15 \mathrm{~s}(7)$.
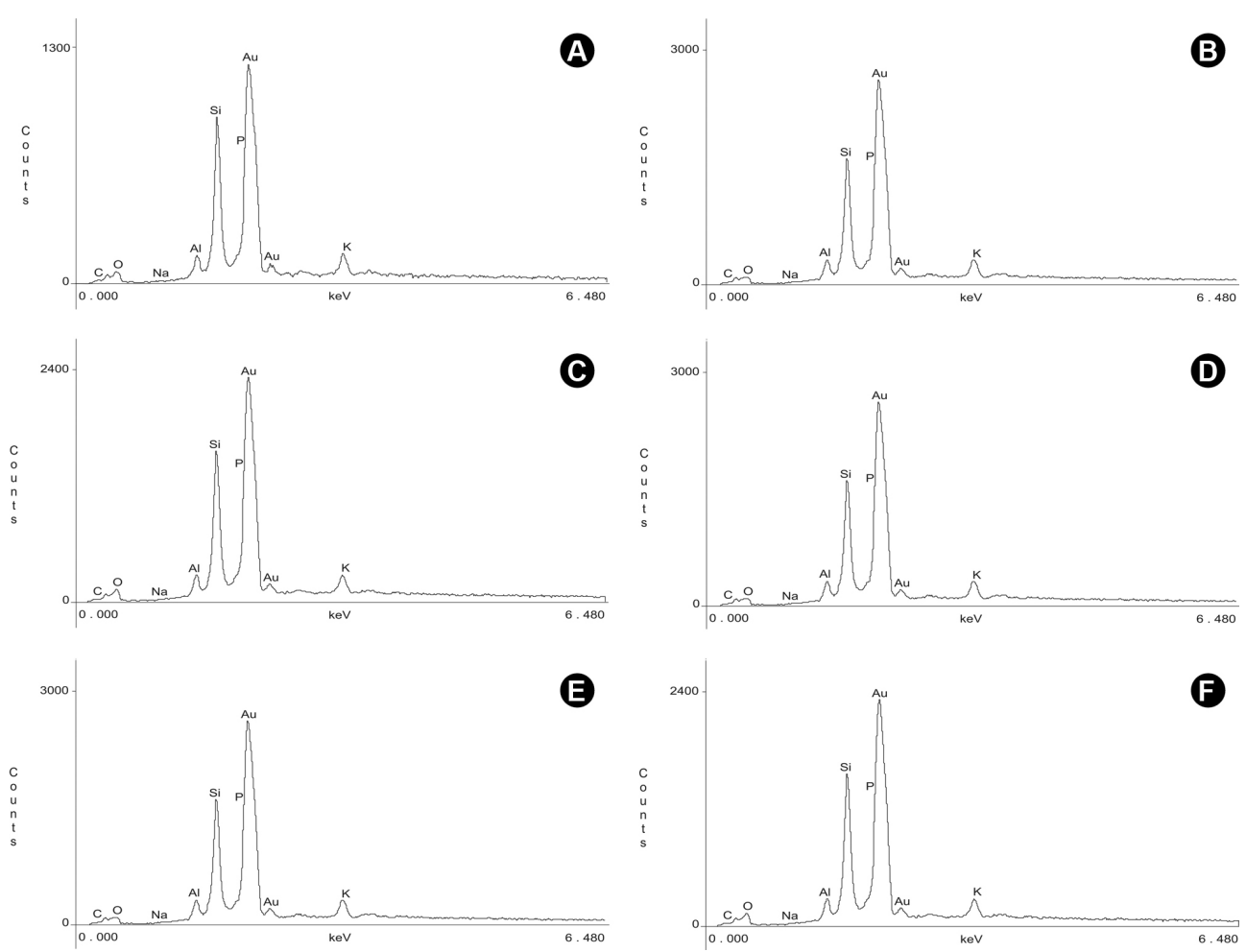

Figure 1. X-ray spectra of a specimen from each group after the surface conditioning indicating presence of feldspar ceramic. 
In order to verify which technique of silane heat treatment provides better values of bond strength, no heating; heating in an oven at $100^{\circ} \mathrm{C}$ for $2 \mathrm{~min}$, and heating with hot air at $50 \pm 5{ }^{\circ} \mathrm{C}$ for 1 min were performed in the present study. Even without the use of etching, similar average bond strength values were seen for the groups that received heat treatment from an oven (G3: $10.47 \pm 0.70)$ and hot air (G5: $9.47 \pm 0.32$ ). This fact can be explained because the resin cements with MDP are hydrolytically stable and, therefore, do not show a reduction in bond strength over time. The addition of a silane coupling agent containing MDP to increase the links of MDP present in the resin cement possibly produced positive results. Yet, the results need to be confirmed after long term aging.

In the presence of alcohol-based solvents, evaporation from the ceramic surface could affect the bond strength. After drying the silane, instead of a monolayer of silane usually an interface with three different structures is observed. The outer layer is composed of small oligomers that are adsorbed to the glass and can be removed by an organic solvent or water at room temperature. The second layer would consist of similar oligomers linked by hydrolyzable siloxane bridges by hot water. The cross-linking is more frequent and uniform in the region closest to the glass surface, forming a regular three-dimensional network that is hydrolytically more stable (7). This last layer is needed to improve adhesion. The removal of the most external layer of silane film could promote adhesion, leaving only the more stable layer that is chemically adsorbed to the surface of the ceramic (7).

The use of a resin luting agent that contains MDP provides a stable chemical union, resistant to hydrolytic degradation. This could explain the resistance values obtained in the group that did not receive heat treatment of the silane (G1: $9.16 \pm 0.64)$. This occurs because these monomers strongly attach to the metal oxides of the ceramic surface by hydrogen bonds and consequently higher bond strength values are obtained when compared to other conventional cements (15).

When the SEM images were analyzed, the ceramic blocks from Groups 1, 2 and 4 presented a surface pattern with pores and grooves provided by etching with HF $(1,11,13)$. However, the SEM images of ceramic blocks in the other groups demonstrated only traces caused by the sandpaper and small pores resulting from the processing of the ceramic block.

SEM analysis of sticks after debonding showed that all failures occurred in the adhesive area. These images were compatible with the information found in the literature, which assert that the microtensile test promotes a higher incidence of adhesive or mixed fractures than macro bond strength tests $(9,10,16-18)$. This also indicates that
MDP based resin cement has less affinity to glass ceramic compared to those of methacrylate based resin cements.

Chemical analysis performed using EDS on one ceramic sample from each study group showed spectra related indicating presence of network of silica $\left(\mathrm{SiO}_{2}\right)$ and either potassium feldspar $\left(\mathrm{K}_{2} \mathrm{O}, \mathrm{Al}_{2} \mathrm{O}_{3}, 6 \mathrm{SiO}_{2}\right)$ or sodium feldspar $\left(\mathrm{Na}_{2} \mathrm{O}, \mathrm{Al}_{2} \mathrm{O}_{3}, 6 \mathrm{SiO}_{2}\right)$ in agreement with other studies $(2,11)$. The percentages of the elements present in the analyzed surfaces is similar between the groups, discarding the possibility of chemical changes caused by heat treatment, as found in one other study (11).

The analyzed groups were subjected to heat treatment of the silane containing MDP, with prior etching with $\mathrm{HF}$ (G2 and G4) showed statistically different bond strength values between them and the control group (G1). The groups that were not exposed to etching ( $\mathrm{G} 3$ and G5), presented similar bond strength values also with the control group (G1). Therefore, according to the results obtained in this current study, performing HF etching may not required for appropriate adhesion since the bond strength did not decrease when this step was eliminated. However, it has to be noted that silane used without prior etching and heat treatment do not promotes high initial bond strength (7). Further studies should be performed to evaluate the long-term durability of bond strength between ceramic and resin cement.

Heat treatment of the pre-hydrolyzed silane containing MDP, in an oven at $100{ }^{\circ} \mathrm{C}$ for 2 min or with hot air at $50 \pm 5{ }^{\circ} \mathrm{C}$ for $15 \mathrm{~min}$, was effective in increasing the bond strength values between the ceramic and resin cement based on MDP monomer providing that failure types were primarily adhesive.

\section{Resumo}

Este estudo avaliou o efeito de diferentes formas de tratamento térmico de um silano pré-hidrolisado na adesão de um cimento resinoso à base de monómeros fosfatados (MDP) à uma cerâmica vítrea. Blocos em resina e cerâmica feldspática $(n=48, n=6$ para teste de união, $n=2$ para microscopia) foram divididos aleatoriamente em 4 grupos e submetidos a tratamentos de superfície: G1-ácido fluoridrico (HF) 9,6\% por $20 \mathrm{~s}$ + Silano + cimento resinoso com MDP (Panavia F) ; G2-HF 9,6\% por $20 \mathrm{~s}+$ Silano + Tratamento Térmico (forno) + Panavia F; G3-Silano + Tratamento Térmico (forno) + Panavia F; G4-HF 9,6\% por $20 \mathrm{~s}+$ Silano + Tratamento Térmico (ar quente) + Panavia F; G5-Silano + Tratamento Térmico (ar quente) + Panavia F; G6-Silano + Panavia F. Teste de microtração (MTBS) foi realizado utilizando máquina de ensaios universal (1 $\mathrm{mm} / \mathrm{min}$ ). Após o descolamento, substrato e superfícies aderentes foram analisadas utilizando estereoscópico e microscópio eletrônica de varredura (MEV) para classificação dos tipos de falha. Os dados foram analisados estatisticamente utilizando o teste ANOVA dois fatores e o teste de Tukey $(\alpha=0,05)$. 0 tratamento térmico do silano contendo MDP, com condicionamento prévio com $\mathrm{HF}(\mathrm{G} 2: 13,15 \pm 0,89$ a e $\mathrm{G} 4: 12,58 \pm 1,03 \mathrm{a})$ resultou em valores de resistência de união significativamente superiores aos do grupo controle $(\mathrm{G} 1: 9,16 \pm 0,64 \mathrm{~b})$. Os grupos sem condicionamento prévio $(\mathrm{G} 3: 10,47 \pm 0,70 \mathrm{~b}$ e $\mathrm{G} 5: 9,47 \pm 0,32 \mathrm{~b})$, apresentaram valores de resistência de união estatisticamente semelhantes entre eles e ao controle (G1). 0 silano utilizado sem condicionamento prévio e tratamento térmico 
apresentou os menores valores de resistência de união $(\mathrm{G} 6: 8,05 \pm 0,37 \mathrm{c})$. As análises em MEV mostraram predominância de falhas adesivas e as análises em EDS demonstraram espectros com elementos semelhantes (Si, Na, Al, K, O, C) caracterizando a microsestrutura da vitro-cerâmica estudada. 0 tratamento térmico do silano pré-hidrolisado contendo MDP, realizado em forno a $100{ }^{\circ} \mathrm{C}$ durante $2 \mathrm{~min}$ ou com ar quente a $50 \pm 5{ }^{\circ} \mathrm{C}$ durante $1 \mathrm{~min}$, foi eficaz no aumento dos valores de união entre cimento resinoso contendo MDP e cerâmica.

\section{References}

1. Della Bona A, Anusavice KJ. Microstructure, composition, and etching topography of dental ceramics. Int J Prosthodont 2002;15:159-167.

2. Brentel AS, Ozcan M, Valandro LF, Alarca LG, Amaral $R$, Bottino MA. Microtensile bond strength of a resin cement to feldpathic ceramic after different etching and silanization regimens in dry and aged conditions. Dent Mater 2007;23:1323-1331.

3. Aida M, Hayakawa T, Mizukawa K. Adhesion of composite to porcelain with various surface conditions. J Prosthet Dent 1995;73:464-470.

4. Ayad MF, Fahmy NZ, Rosenstiel SF. Effect of surface treatment on roughness and bond strength of a heat-pressed ceramic. J Prosthet Dent 2008:99:123-130.

5. Matinlinna JP, Vallittu PK. Bonding of resin composites to etchable ceramic surfaces - an insight review of the chemical aspects on surface conditioning. J Oral Rehabil 2007;34:622-630.

6. Fabianelli A, Pollington $S$, Papacchini F, Goracci C, Cantoro A, Ferrari $M$, et al.. The effect of different surface treatments on bond strength between leucite reinforced feldspathic ceramic and composite resin. J Dent 2009;38:39-43.

7. Hooshmand $T$, van Noort $R$, Keshvad A. Bond durability of the resinbonded and silane treated ceramic surface. Dent Mater 2002;18:179188.
8. Moharamzadeh $K$, Hooshmand T, Keshvad A, van Noort R. Fracture toughness of a ceramic-resin interface. Dent Mater 2008;24:172-177.

9. Sano $H$, Shono $T$, Sonoda $H$, Takatsu $T$, Ciucchi B, Carvalho $R$, et al.. Relationship between surface area for adhesion and tensile bond strength--evaluation of a micro-tensile bond test. Dent Mater 1994;10:236-240.

10. Pashley DH, Carvalho RM, Sano H, Nakajima M, Yoshiyama M, Shono $Y$, et al.. The microtensile bond test: a review. J Adhes Dent 1999;1:299309.

11. de Carvalho RF, Martins ME, de Queiroz JR, Leite FP, Ozcan M. Influence of silane heat treatment on bond strength of resin cement to a feldspathic ceramic. Dent Mater J 2011;30:392-397.

12. Chen $\mathrm{JH}$, Matsumura $\mathrm{H}$, Atsuta M. Effect of different etching periods on the bond strength of a composite resin to a machinable porcelain. J Dent 1998;26:53-58

13. Canay S, Hersek N, Ertan A. Effect of different acid treatments on a porcelain surface. J Oral Rehabil. 2001;28:95-101.

14. Hooshmand T, van Noort R, Keshvad A. Storage effect of a pre-activated silane on the resin to ceramic bond. Dent Mater 2004;20:635-642.

15. Hummel $M$, Kern M. Durability of the resin bond strength to the alumina ceramic Procera. Dent Mater 2004;20:498-508.

16. Della Bona A, Anusavice KJ, Shen $\mathrm{C}$. Microtensile strength of composite bonded to hot-pressed ceramics. J Adhes Dent 2000;2:305-313.

17. Shono $Y$, Terashita M, Shimada J, Kozono Y, Carvalho RM, Russell CM, et al.. Durability of resin-dentin bonds. J Adhes Dent 1999;1:11-18.

18. Phrukkanon S, Burrow MF, Tyas MJ. The influence of cross-sectional shape and surface area on the microtensile bond test. Dent Mater $1998 ; 14: 12-21$.

Received September 4, 2014 Accepted November 27, 2014 